\title{
The Implosion of Global Liberal World Order and Russian Foreign Policy: Dimensions, Tensions, and Prospects
}

\author{
L.V. Kochtcheeva \\ North Carolina State University, Raleigh, USA
}

\begin{abstract}
The world faces a strategic challenge of reforming the governance basis of international politics, which is displaying the symptoms of significant destabilization, searching for new ways of crafting nuanced equilibria of interests and capacity at the global, regional, and domestic levels. Developing intricate and adaptable formulas to manage individual facets of international engagement is becoming increasingly complex and volatile. The effects of instability vary in different countries, but the global operational and political space is increasingly determined by problems within countries, where external stress becomes a result of domestic discrepancies, aggravating them and producing a set of contradictions. In the context of profound global transformations, what explains Russia's status and positioning in the world? This article argues that as states are struggling to adapt to new realities and acquire capabilities in an effort to survive or gain more influence, Russia's standing will depend on how adequately it can respond to the challenges and how effectively it will be able to use its advantages. Russia should not simply take in the results of global turbulence, but rather employ and actively develop areas of leadership and collaboration, by tying foreign policy firmly to the priorities of domestic development. While Russia conducts an active foreign policy consistently defending its interests and combining efforts to find optimal solutions to many contemporary problems, it has not yet arrived at a coherent security strategy or produced a vision of a future world order. The success may depend on understanding of the current trends, recognizing opportunities and demonstrating leadership, willingness to share in responsibility for results, as well as conducting essential domestic reforms.

Key words: Global (international) order, Russian foreign policy, national interests, global governance, multipolar international system, international community, cooperation, globalization, transition, economic challenges
\end{abstract}

For citation: Kochtcheeva, L.V. (2020). The Implosion of Global Liberal World Order and Russian Foreign Policy: Dimensions, Tensions, and Prospects. Vestnik RUDN. International Relations, 20 (3), 463-475. DOI: $10.22363 / 2313-0660-2020-20-3-463-475$

\section{Разрушение мирового либерального миропорядка и российская внешняя политика: направления, противоречия и перспективы}

\author{
Л.В. Кощеева \\ Университет штата Северная Каролина, Роли, США
}

Современный мир стоит перед стратегической задачей по реформированию основ управления международной политикой, которая демонстрирует признаки значительной дестабилизации. Происходит поиск новых способов достижения равновесия интересов на глобальном, региональном и национальном уровнях. Разработка сложных и адаптируемых формул для управления отдельными аспектами международного

(C) Kochtcheeva L.V., 2020

This work is licensed under a Creative Commons Attribution 4.0 International License.

https://creativecommons.org/licenses/by/4.0/ 
взаимодействия становится все более сложным и нестабильным. Последствия нестабильности в разных странах различны, однако кризисные явления на глобальном уровне все больше определяются внутриполитическими проблемами отдельных стран. Что же объясняет статус и позицию России в мире в контексте этих глобальных преобразований? Автор статьи утверждает, что, поскольку государства активно пытаются адаптироваться к новым реалиям в целях выживания или усиления влияния, положение России будет зависеть от того, насколько адекватно она сможет реагировать на вызовы и насколько эффективно она сможет использовать свои преимущества. Россия должна не просто воспринимать результаты глобальной турбулентности, а скорее использовать и активно развивать свое сотрудничество, твердо связывая внешнюю политику с приоритетами внутреннего развития. Хотя Россия и проводит активную внешнюю политику, последовательно отстаивая свои интересы и объединяя усилия для поиска оптимальных решений многих современных проблем, она еще не сформулировала согласованную стратегию безопасности и не выработала видение будущего мирового порядка. Успех может зависеть от понимания текущих тенденций, признания возможностей и демонстрации своего лидерства, готовности разделить ответственность за результаты, а также проведения важных внутренних реформ.

Ключевые слова: глобальный (международный) порядок, российская внешняя политика, национальные интересы, глобальное управление, многополярная международная система, международное сообщество, сотрудничество, глобализация, переходный период, экономические вызовы

Для цитирования: Kochtcheeva L.V. The Implosion of Global Liberal World Order and Russian Foreign Policy: Dimensions, Tensions, and Prospects // Вестник Российского университета дружбы народов. Серия: Международные отношения. 2020. Т. 20. № 3. С. 463 - 475. DOI: 10.22363/2313-0660-2020-20-3-463-475

\section{Introduction: The World in Motion}

At the turn of the 21 st century few thought that an interdependent liberal world order could be significantly challenged. Open markets, powerful interlinkages, permeable borders, information and communications revolution, and fusing cultures seemed to promise its permanence. However, the liberal order started to exhibit "its own signs of deterioration", with the international architecture created by the West becoming unstable and uneven [Monaghan 2016], with liberalism yielding to balance-ofpower politics [Mearsheimer 2018], and nationalism and protectionism reasserting themselves $^{2}$. The growing discontent among a number of actors over the global politics, over the highly uneven distribution of material wealth, over rulemaking and rule-breaking, and "over when and whether might makes right" [Legvold 2017] produced many challenges to the world order. The international setting started shifting

${ }^{1}$ Haass R. How a World Order Ends: And What Comes in Its Wake // Foreign Affairs. 2019. January/February. URL: https://www.foreignaffairs.com/articles/2018-12-11/ how-world-order-ends (accessed: 14.10.2019).

2 Deudney D., Ikenberry G.J. Liberal World. The Resilient Order // Foreign Affairs. 2018. July/August. URL: https://www.foreignaffairs.com/articles/world/201806-14/liberal-world (accessed: 14.10.2019). and the task for the countries became to figure out how to build foreign policy, domestic responses, and international relations when key aspects of the international order are set in motion.

The global interconnectedness also made it necessary to take a fresh look at the concept of the universal commons, including health, global climate change, conservation, migration, and others. Global environmental change has intensified the ties of interdependence, but these ties are embodied in very different and unequal experiences. The improved conditions and the global citizenship of some are dependent on "sub-citizenship of others" [Sparke 2013: 21]. Moreover, there are unresolved contradictions between the more globalized economic structure of the world, and the political facet, in which universal and effective mechanisms of global governance have never been established. The concepts of international community and cooperation to a large degree remain mostly aspirational and highly dependent on domestic political will and capacity, especially in the times of global crises ${ }^{3}$.

3 Haass R. The Pandemic Will Accelerate History Rather Than Reshape It Not Every Crisis Is a Turning Point // Foreign Affairs. April 20, 2020. URL: https://www.foreignaffairs.com/articles/united-states/2020- 
The current COVID-19 pandemic demonstrates that the primary responses to the health crisis have been national, not international or global. While some countries, including Russia and China, aided the US, Italy, Serbia and other countries, the emphasis remained on national well-being. When the calamity passes, the emphasis will move onto national socioeconomic revival with the source of political legitimacy of any state remaining at the domestic level. The new conditions, which actively intervene in the lives of states and people, provoke a rethinking of governance, institutions, and self-identification in a changing environment ${ }^{4}$.

Domestication of decisions that influences the functioning of the global world order remains the challenge to that same order. States continue to act in a way that reflects their national pursuits, yet, no truly autonomous solutions seem to be possible. Global health may present the ultimate opportunity in which the interdependencies could come together to shape local and global destinies. Any autonomous action of especially major powers leads to global implications. A critical component of adjustment between global and domestic elements is needed as a result of changing capacities, and the failure of current arrangements to cope with the challenges associated with globalization.

The world faces a strategic challenge of reforming the governance basis of international politics, which is displaying the symptoms of significant destabilization, searching for new ways of crafting nuanced equilibria of interests and capacity at the global and domestic levels. The nature of instability is increasingly determined by problems within countries, by the levels of rivalry between them, and by the tensions in global and regional international political and economic orders. Uncertain global cooperation, weakening American leadership, China's world leadership ambitions, great power conflict, including tensions between Russia and

04-07/pandemic-will-accelerate-history-rather-reshape-it (accessed: 22.04.2020).

${ }^{4}$ Lukyanov F., Krastev I. New Rules or No Rules? // 11 th Annual Valdai Discussion Club Meeting Participants' Report. 2015. P. 1-28. the West, portrayed the international environment before the appearance of current health crisis.

Developing intricate and adaptable formulas to manage facets of international engagement by individual countries is becoming increasingly complex and volatile. The effects of instability vary in different countries, but the global operational and political space is increasingly determined by problems within countries, where external stress reflects domestic discrepancies, aggravating them and producing a set of contradictions.

In the context of profound global transformations, what explains Russia's status and positioning in the world? As states are struggling to adapt to new realities and acquire capabilities in an effort to survive or gain more influence, Russia's standing will depend on how adequately it can respond to the challenges and how effectively it will be able to use its advantages. Russia should not simply take in the results of global turbulence, but rather employ and actively develop areas of leadership and collaboration, by tying foreign policy firmly to the priorities of domestic development. While Russia conducts an active foreign policy consistently defending its interests and combining efforts to find optimal solutions to many contemporary problems, it has not yet arrived at a coherent security strategy or produced a vision of a future world order. The success may depend on understanding of the current trends, recognizing opportunities and demonstrating leadership, willingness to share in responsibility for results, as well as effecting necessary domestic reforms.

\section{The Discontents of the Global Liberal World Order}

The world enters the era of shaping a number of very different ways of managing international relations, the state, and society, which are carried out simultaneously, coming into a complex, often highly conflicting interaction. These developments do not merely mirror the intersection of geopolitical interests, but also signal about the clash of completely different principles that takes roots in different 
political, cultural and historical traditions [Karaganov, Suslov 2018]. The accumulated failures of the world system gave an aggregate effect, provoking imbalances in the whole system ${ }^{5}$.

While there are diverse interpretations of the forces and causes of disruption to the global order, the hegemony of the liberal world order is deemed to be over [Duncombe, Dunne 2018]. Many in academia, official and policy circles, and media agree with how Richard Haass explains the current state of the world: "...effective statecraft is conspicuously lacking. Institutions have failed to adapt. Efforts to build effective frameworks to deal with the challenges of globalization, including climate change and cyberattacks have come up short" . Yet while the world order may be "crumbling", there is significant uncertainty about the global design that may take its place.

The advocates and critics of the liberal world order note that the challenges come in several fundamental ways: first, through a failure of Western, especially the US leadership; second, through the rising authority of the Rest; and third, through the crisis of globalization.

The problems of the global order are linked to the quality and legitimacy of global leadership. For many years, the proponents of the global liberal world defended it as an open, 'rules-based order' for the international community, established by the Western states. The role of the United States in both shaping and defending it has been critical. American military power, the dynamism of the U.S. economy, the great number of close alliances, and moral superiority thesis provided the critical architecture. In short, the successes of a liberal world arose from the fact that American power was unrivaled. When the hegemon, however, is becoming unable or willing to uphold the norms

5 Barabanov O., Bordachev T., Lissovolik Y., Lukyanov F., Sushentsov A., Timofeev I. Living in a Crumbling World // Valdai Club Annual Report. 2018. P. 1-28.

6 Haass R. Liberal World Order, R.I.P. // Project Syndicate. March 21, 2018. URL: https://www.projectsyndicate.org/commentary/end-of-liberal-world-order-byrichard-n--haass-2018-03 (accessed: 14.10.2019). and rules it claims promote, the global world order slips into a 'crisis of authority' [Ikenberry 2015: 451].

The illiberal methods that portrayed the US 'war on terror', the invasions of Afghanistan and Iraq, the withdrawal from a range of multilateral treaties, the stance of the Trump administration on trade, environment and alliances have been sharp indications of a complex disconnection from liberal values. A weakening of the US commitment or its capabilities within the global order invariably leads to the weakening of its leadership, calling the rules of the order into question. Uncertainties in Europe, Britain's decision to leave the EU, spikes in populism and separatism, a massive immigration crisis, and a many other dilemmas troubling Europe, put a question mark on long project of building a union. A great transition is happening from a situation where the US hegemony relied on its capacities and support by the allies, to erratic interaction in conditions when respect for the American political and economic model is decreasing, while the number of players, who began to seek greater autonomy, increasing. Globally, the US and its allies seem to fail to provide "an example to others of the strength of liberal systems of economic and political governance"7.

The shaking of the global order might be leading to a kind of post-US and post-Western order that is increasingly shared with nonWestern rising states [Ikenberry 2018]. Powerful non-Western states are beginning to advance their own agendas and ideas for global order, while critics of the unipolar model doubt the effectiveness and validity of the rules of the order implied by the liberal model. The order does not reflect the new distribution of global power. China, Russia and other countries do not see the structure of the order as legitimate, and they continue to contest it [Kanet 2018].

In the liberal view, such disenchantment with the order reflects the rise of

7 Niblett R. Liberalism in Retreat: The Demise of a Dream // Foreign Affairs. 2017. January/February. URL: https://www.foreignaffairs.com/articles/2016-12-12/ liberalism-retreat (accessed: 13.02.2020). 
authoritarianism, protectionism, nationalism, fragmented system of blocs, spheres of influence and regional great power projects ${ }^{8}$. Yet, there are alternative scenarios to rivalry and security competition. China may be seen as trying not to overthrow current order, but build up its leadership and influence within it, while Russia advocates a concept of a polycentric world with a community of equal partners. The imposition of order is no longer possible, though, as the global world is too complex and international environment is too multifaceted for unilateralism.

There is a need to create global governance, not order, aimed at the resolution of emerging and growing problems through institutions-based cooperation between states embracing particular political and economic importance ${ }^{9}$. The support of multipolarity has now become a complex protection of multi-level pluralism as well as the pluralism of state-centric international relations defending the autonomy and the universalism of international society, with the UN and other international institutions ensuring its democratic nature [Sakwa 2017]. In any case, the scale of the developments signals that the current trends are doubtful to continue without any aftereffects. In the words of Ivan Timofeev, "China is too big for the old order; Russia is too assertive and independent for it" $" 10$.

Globalization is also exacerbating economic inequality, financial imbalances, and cultural preferences which remain without remedy [Kochtcheeva 2020]. Globalization stimulates not only an open and happy world, but also

8 Deudney D., Ikenberry, G.J. Liberal World. The Resilient Order // Foreign Affairs. 2018. July/August. URL: https://www.foreignaffairs.com/articles/world/201806-14/liberal-world (accessed: 14.10.2019); Wright T. The Return to Great-Power Rivalry Was Inevitable // The Atlantic. September 12, 2018. URL: https://www.theatlantic. com/international/archive/2018/09/liberal-internationalorder-free-world-trump-authoritarianism/569881 (accessed: 27.03.2020).

9 Barabanov O., Bordachev T., Lissovolik Y., Lukyanov F., Sushentsov A., Timofeev I. Living in a Crumbling World // Valdai Club Annual Report. 2018. P. $1-28$.

10 Timofeev I. A New Anarchy? Scenarios for World Oder Dynamics // Valdai Discussion Club Report. 2019. P. 4. URL: https://valdaiclub.com/files/25352/ (accessed: 27.03.2020). conflicts and hierarchies of power, asymmetrical exchanges, and risks in the turbulent world [Dasgupta 2004]. It may deform social systems causing fragmentation of the global community, increasing the tendency of people to polarize along group lines, and leading to new conflicts. Globalization specifically draws attention to environmental and health concerns, social ecology, and humanity. Health pandemics, climate change, increased migration, terrorism, uneven interdependence, religious wars, interethnic conflicts, and armed separatism lead to the actualization of traditional security threats and involve individual countries and entire regions.

The new COVID-19 crisis is turning to be an enormous "stress test for globalization... forcing a major reevaluation of the interconnected global economy"11. While crucial supply chains break down, travel increases rapid spread of contagious disease, firms and entire countries realize their vulnerability, a shift in power dynamics among major world economies is taking place. These processes challenge the resilience of the current global world order. The nature of instability is increasingly determined by problems within countries, by the levels of rivalry between them, and by the tensions in global and regional international political and economic realms. International disagreement is becoming the result of internal challenges, aggravating them, and forming a tight twist of tensions and contradictions. These contradictions between countries cast doubt on the very conceptual basis of global order.

\section{The Inconvenient Birth of Russian Foreign Policy}

The analysis of the Russian foreign policy is impractical without considering its difficult beginning, which started with the collapse of statehood, geopolitical retreat and the downfall of superpower status. Despite the mounting

11 Farrell H., Newman A. Will the Coronavirus End Globalization as We Know It? The Pandemic Is Exposing Market Vulnerabilities No One Knew Existed // Foreign Affairs. March 16, 2020. URL: https://www.foreignaffairs. com/articles/2020-03-16/will-coronavirus-endglobalization-we-know-it (accessed: 10.05.2020). 
problems, the Soviet Union almost until its collapse retained the features of one of two superpowers and associated opportunities on the world stage. Suddenly, Russia was forced verify its international standing and recognition, as well as plead for economic assistance. Russia's aspirations to enroll into the community of the Western states on an equal basis did not realize. While the West celebrated an unexpected victory and proclaimed a new world order based on liberal principles, Russia struggled to survive fighting economic challenges, wars inside its own territory, and social demoralization.

Russia underwent a political and socioeconomic transition and incorporation into the globalizing world, adopting the Western course of transformations. It had become a state with open borders, an unsound economy, a frail army, an undetermined identity, and a lack of reliable allies. Realizing its technological backwardness and the weakness of the available political mechanisms for conducting an independent foreign policy, Russia adopted the US global leadership, and its mission became to find a suitable place in its framework. Relatively quickly, however, the country became disenchanted with the position of the West, which used the advantages brought by the end of the Cold War including NATO's eastward expansion, while Russia bore massive costs in all areas of transformation.

Post-Cold War Russia did not fully conform to Western expectations and hopes for its transformation, as well as the West was not able to effectively interpret Russian behavior [Torkunov 2012; Bordachev 2018]. Staying outside the collective security arrangement embodied by NATO, compelled Russia to generate a new concept of international relations, defining the conditions for great powers to recognize the sovereignty, security and other national interests of other countries in a legitimate way [Safranchuk 2018]. Any Russian attempt to fit into the political, ideological and value system created by the West without Russia's participation and without taking its interests into account did not agree with the implied one-sided adaptation to West-promoted liberal order [Lukyanov 2020]. As a reemerging state, Russia strived for recognition and inclusion to ensure that the post-Cold War power shift would be characterized by interlinkages, interdependencies, and an expanded collective security system. Russia was offering the USA and Europe schemes of rapprochement and cooperation that would allow Russia become part of "the Historical West" [Sakwa 2017: 23], while maintain its own strategic sovereignty. The liberal world order, however, did not allow for any interpretations of its representation, expecting unconditional submission to the established rules or exclusion.

The changes in Russian foreign policy took place under a clear recognition that there is no suitable niche for Russia in the global system, which stimulated conversations and ideas about the role and place of Russia the global world. Russia insisted that it was an important power in Europe and that the post-Cold War move which claimed a certain universality for the liberal international order was objectionable. Russia chose to follow its own path of development, defending its own national interests and its role in the international arena in the context of both positive and negative outcomes of the globalizing world. Russian foreign policy also developed a more unilateralist and anti-Western course, echoing the change in the perceptions and priorities of Russia's national interests. The challenge became about how to balance the scale of own interests with needs and available capacities.

\section{Trends in Russian Foreign Policy}

Russia is re-conceptualizing its role and image as an international actor and its relations with the major actors and processes of global order. Until recently, Russian foreign policy was largely determined by the consequences of the events of the late twentieth century. External challenges, survival, recovery, self-affirmation pushed the country to make difficult decisions, reinforcing the attention to national interests and goals, re-evaluating ideological influence, as well as preserving national value system.

The manner that Russia projects itself in the world is also determined by whether or not the 
actions of the Western powers are perceived by the Russian leadership as accepting Russia on an equal and just footing internationally [Tsygankov 2019; 2020; Lukyanov 2020]. The changing international circumstances demand from Russia a flexible and timely response to new challenges, which arise in the course of the evolution of the entire system of global development. At the same time, Russia finds itself in the process of transformation, having new opportunities for development and an adequate response to the challenges and threats, changing the structure of its national security and interests, reflected in the concepts of foreign policy, economic prerogatives and cultural preferences.

The concept of a "multipolar world", "polycentric world", and a "diversity in the world" emerged as practically the official foreign policy doctrine of Russia [Trenin 2018; Colton 2016; Kanet 2018; Kortunov 2019]. The mounting concerns that Russia's interests are not only taken into consideration, but also are not seemingly heard, prompted the Russian leadership to speak assertively about the concept of multipolarity. The Russian Foreign Policy Concept of 2016 specifically stresses that "the world is currently going through fundamental changes related to the emergence of a multipolar international system"12. The appeal and historical destiny of multipolar world in the Russian interpretation of multipolarity also envisions the imperative for an equitable dialogue with other centers of power, including China and India who believe that a multipolar world is the most attractive concept ${ }^{13}$. Russia aims at the global component in its international strategy as a participant in creation of the rules and norms for the new world order together with other actors.

12 Foreign Policy Concept of the Russian Federation (approved by President of the Russian Federation Vladimir Putin on November 30, 2016) // The Ministry of Foreign Affairs of the Russian Federation. December 1, 2016. URL: $\quad$ https://www.mid.ru/en/foreign_policy/official_ documents/-/asset_publisher/CptICkB6BZ29/content/id/ 2542248 (accessed: 14.02.2020).

13 Timofeev I. A New Anarchy? Scenarios for World Oder Dynamics // Valdai Discussion Club Report. 2019. P. 1-31. URL: https://valdaiclub.com/files/25352/ (accessed: 27.03.2020).
Russia views this new order as polycentric where various centers of power participate in the world and regional relations, contribute to global governance, and have certain autonomy or independence in conducting foreign policy, especially in the regions and with countries close to its spheres of interest. Russia, however, does not have a goal at world domination, and it is not keen to rebuild the Soviet Union, but it intends to restore itself as a great power addressing regional and global concerns ${ }^{14}$.

Global order and globalization are viewed in Russian foreign policy mainly through the lens of realism. As such, global affairs live together with national interests, sovereignty, national security, power and polarity. The assertive stance of contemporary Russian foreign policy is a combination of measures for attaining Russia's goal of joining the highest rank of global politics and security as an equal partner with the United States and other global leaders. Russia's strategic goal is to advance its role in the world using its geopolitical position, resources, military capabilities, as well as cultural and human capital, despite unfavorable external and domestic circumstances, and to try to exert influence on the process on new world order formation [Mankoff 2009; Makarychev 2014; Sakwa 2014; Freedman 2014].

Russia's responses to the external challenges constitute a long-term policy change, reflecting a pattern of Russia's more assertive relations with the West and other nations. Such a development of Russian foreign policy is not a result of recent crises, including a stand-off with the West, but rather a strategic development of national policy. Russian determinism is also reinforced by a continued commitment to the institutions of international society [Sakwa 2017]. Russia aspires to remain open to joint constructive work with foreign partners in all geographical areas and in any formats based on mutual respect, reliability, and negotiability, which also fully applies to the United States, the

14 Trenin D. Russia's Foreign Policy in the Next Five Years: Goals, Incentives, Benchmarks // Moscow Carnegie Center. April 28, 2016. URL: https://carnegie.ru/2016/ 04/28/ru-pub-63462 (accessed: 14.05.2020). (In Russian). 
West as a whole, as well as to such structures as the EU and NATO ${ }^{15}$.

Russia has always been open to bilateral and multilateral relationships and will continue to participate in the processes of integration and expanding cooperation. The country's agenda is built on the principles of mutual respect and nonexclusion, as the country works with a range of organizations, including the Eurasian Economic Union, the Shanghai Cooperation Organization, the BRICS, the advancement of the RIC (Russia, India and China) format, and others. The move from Europe to Euroasia, and especially China, in the second half of the 2010s could be seen as "a turn of Russia toward itself - in search of a point of equilibrium in a rapidly changing global environment. Russia's current self-determination looks like asserting itself as a large independent entity located in the north of the Eurasian continent, directly adjacent to East and Central Asia, Europe, the Near and Middle East"16.

Russia's foreign policy has been considered a significant success, especially compared to the continuing uncertainty and irregularity that has developed in the international system ${ }^{17}$. The key to such achievement is found in the evident emphasis on its interests, effective crisis management skills, refusal to impose any

${ }^{15}$ Lavrov S. Speech at a General Meeting of Members of the Russian International Affairs Council // Russian International Affairs Council. November 20, 2018. URL: https://russiancouncil.ru/analytics-and-comments/analytics/ vystuplenie-na-obshchem-sobranii-chlenov-rossiyskogosoveta-po-mezhdunarodnym-delam/ (accessed: 14.05.2020). (In Russian).

16 Trenin D. 20 Years of Vladimir Putin: Transformation of Foreign Policy // Vedomosti. August 13, 2019. URL: https:/www.vedomosti.ru/opinion/articles/ 2019/08/14/808755-20-let-putina (accessed: 30.03.2020). (In Russian).

${ }^{17}$ Ivanov I. Russian Foreign Policy Moving into 2020: Today's Achievements and Tomorrow's Challenges // The Moscow Times. December 2, 2019. URL: https://www.themoscowtimes.com/2019/12/02/in-a-yearmarked-by-global-chaos-russia-remained-a-reliablepartner-a68426 (accessed: 14.12.2019); Karaganov S. Where to Go and with Whom to Go: Russia's Foreign Policy on the Threshold of a New Decade // Russia in Global Affairs. January 28, 2020. URL: https://eng.globalaffairs.ru/articles/where-to-go-and-withwhom-to-go-russias-foreign-policy-on-the-threshold-of-anew-decade/ (accessed: 14.05.2020). geopolitical model on other countries, good knowledge of the region and the ability and willingness to pursue policies based on local realities. Syria and the Middle East more broadly are justly assumed to be among Russia's most successful foreign policy accomplishments. Russia's turn to the East has also considerably changed the balance of power in relations with the West, especially Europe. Russia continues to be a strong diplomatic player, who is interested in combining efforts in order to find optimal solutions to many contemporary problems. Collaboration is especially relevant today, when there is a dangerous accumulation of conflict potential in the world ${ }^{18}$.

Russia insists on the need for countries to be able to develop an optimal approach for obtaining mutual benefits, while maintaining the space for foreign policy maneuver and the guarding security interests. Russian foreign policy is aimed at a constructive international agenda and effective resolution of common pressing problems, from creating a global antiterrorist coalition to building an architecture of security and broad cooperation in Eurasia. The priorities of the foreign policy remain open: "It is building confidence, fighting common threats for the whole world, expanding cooperation in the economy, trade, education, culture, science and technology, removing barriers to communication between people"19.

In the last ten years the strategic line of Russian international behavior has also consisted of challenging the US-led promoters of globalization to secure the search for new rules of the game in global multipolar politics [Kanet

18 Foreign Minister Sergey Lavrov's remarks at the Moscow Conference on International Security, Moscow, April 242019 // The Ministry of Foreign Affairs of the Russian Federation. April 24, 2019. URL: https://www.mid.ru/ru/press_service/minister_speeches//asset_publisher/7OvQR5KJWVmR/content/id/3624959?p _p_id=101_INSTANCE_7OvQR5KJWVmR\&_101_INST ANCE 7OvQR5KJWVmR_languageId=en_GB (accessed: 27.04.2019).

${ }^{19}$ Putin V.V. Message from the President to the Federal Assembly // The President of Russia official website. February 20, 2019. URL: http://kremlin.ru/events/ president/transcripts/messages/59863 (accessed: 02.04.2020). (In Russian). 
2018]. Russia has already demonstrated it can handle some of the most acute challenges of regional and global security. Currently, it has the opportunity to show that it is also a skilled architect who is prepared, along with its partners, to advance individual mechanisms, principles, and models of the new world order that is still under construction ${ }^{20}$.

The development of new ways and niches of international cooperation for the future is of growing importance. Such areas as global energy security, food security, cyber-security, cooperation on climate and environmental issues are promising. A main concern is the development of an international system that would ensure stability and security at all levels, helping to neutralize the current challenges and threats and preventing the appearance of new ones. There are objective preconditions for shaping an inclusive global order in which each state would assume its share of responsibility for the future of humanity, and in which the global community protects international law and the legitimate interests of each of its members.

Russian foreign policy and global views are not without a lot of controversy. The West views it as aggressive, hostile, antagonistic, "posing the greatest challenges to the world order" and creating risks in "the relatively peaceful and prosperous international order created and sustained by the United States"21.

${ }^{20}$ Ivanov I. Russian Foreign Policy Moving into 2020: Today's Achievements and Tomorrow's Challenges // The Moscow Times. December 2, 2019. URL: https://www.themoscowtimes.com/2019/12/02/in-a-yearmarked-by-global-chaos-russia-remained-a-reliablepartner-a68426 (accessed: 14.12.2019).

21 Diamond L. Russia and the Threat to Liberal Democracy: How Vladimir Putin Is Making the World Safe for Autocracy // The Atlantic. December 9, 2016. URL: https://www.theatlantic.com/international/archive/ 2016/12/russia-liberal-democracy/510011/ (accessed: 14.10.2019); Kagan R. The Twilight of the Liberal World Order. Brookings Big Ideas for America // Brookings Institute. January 24, 2017. URL: https://www.brookings. edu/research/the-twilight-of-the-liberal-world-order/ (accessed: 14.10.2019); Ringen S. Vladimir Putin Has Turned Russia into an Unapologetic Autocracy. What's His End Game? // Los Angeles Times. May 16, 2018. URL: https://www.latimes.com/opinion/op-ed/la-oe-ringenputin-russia-20180516-story.html (accessed: 14.10.2019); Wright T. The Return to Great-Power Rivalry Was
Reincorporation of the Crimea, situation in the south-east of Ukraine, military and diplomatic victories in Syria, and regional assertiveness in Eurasia produce a lot of condemnation leading to sanctions. Russia's foreign policy is believed to be moved by fear of regime change, a need to distract its own population from domestic problems, and anxiety about NATO eastward advance [Miller 2019].

Especially popular among the West became the assertions of Russia's intent to restore the "Soviet empire", launch efforts to revise the US security arrangements, and the necessity to counteract such tendencies, using a wide array of methods, not excluding the return to the Cold War policies to contain Russia ${ }^{22}$. It is also believed that Russian foreign policy cannot be properly understood without grasping "Putin's personal idiosyncrasies and worldviews" [Gotz 2017: 230]. Confrontational rhetoric and policies toward Russia, imposition of restriction, talking from the position of power and containing Russia's "expansion", rather than discussing cooperation and shared interests dominate the West's attitude toward Russia's foreign policy ${ }^{23}$.

Russian foreign policy and Russia's role and presence in the world, notwithstanding any polemics, have increased significantly. In essence, this means that an important accomplishment was achieved in the political history of the country, which is the overcoming of the consequences of the collapse of the USSR, which meant an unprecedented retraction in opportunities,

Inevitable // The Atlantic. September 12, 2018. URL: https://www.theatlantic.com/international/archive/2018/09/ liberal-international-order-free-world-trumpauthoritarianism/569881 (accessed: 27.03.2020).

22 Goldgeier J. To Contain Russia the U.S. Should Return to Cold War Policies // New Republic. November 7, 2014. URL: https://newrepublic.com/article/120140/25years-after-fall-berlin-wall-new-containment (accessed: 14.10.2019); Mandelbaum M. The New Containment: Handling Russia, China and Iran // Foreign Affairs. 2019. March/April. URL: https://www.foreignaffairs.com/ articles/china/2019-02-12/new-containment (accessed: 14.10.2019).

${ }^{23}$ Ashford E. How Reflexive Hostility to Russia Harms U.S. Interests: Washington Needs a More Realistic Approach // Foreign Affairs. April 20, 2018. URL: https://www.foreignaffairs.com/articles/russian-federation/ 2018-04-20/how-reflexive-hostility-russia-harms-usinterests (accessed: 14.10.2019). 
status, and prestige on the world stage. Russia returned to the global arena as one of the largest and most active geopolitical and military players, actively interacting with all of its vast neighborhood and being guided only by her own interests.

\section{Challenges and Prospects for the Future}

The process of crushing global order and transitioning to a new one forces us to re-think the role and position of Russia in the world, its contribution to the building of the future order, its own interests, as well as principles of justice and mutual respect in the global community. The current pandemic sharpened the tendencies that have been developing the previous years, including global fragmentation, more aggressive pursuit of national interests, and increased great power competition. Appeals and hopes for a transnational response to the pandemic did not realize, and countries pursued national responses to a global crisis.

Still, no truly autonomous answer seems to be possible to a global problem. Probably the most dangerous scenario could be coming out of this pandemic, in anticipation of some new global threat, not having any agreement on how to $\mathrm{act}^{24}$. The world faces a strategic challenge associated with the formation of its operational and political space filled with those institutions where countries can realize their political and socio-economic potential. But global governance, multilateralism, and a universal combination of efforts are only the right answer when they consider the interests of everyone.

Is deterioration of the world order beneficial for Russia? It does create opportunities for Russia to participate in the design of the new order, cultivate relationships, and advance its own interests ${ }^{25}$. A priority task for Russian

${ }^{24}$ Lavrov S. It Is Necessary to Investigate the Causes of the Pandemic, but Not to "Point the Finger" // Russian International Affairs Council. April 29, 2020. URL: https://russiancouncil.ru/analytics-and-comments/ comments/prichiny-pandemii-rassledovat-nuzhno-no-netykat-paltsem/ (accessed: 14.05.2020).

${ }^{25}$ Ivanov I. Russian Foreign Policy Moving into 2020: Today's Achievements and Tomorrow's Challenges // The Moscow Times. December 2, 2019. URL: https://www.themoscowtimes.com/2019/12/02/in-a-year- foreign policy is the development of such a world order that would guarantee stability and security at all levels, helping to neutralize the current challenges and threats and preventing the appearance of new ones. The problem lies, however in constructing a delicate balance between the need to find a mission, a big idea, a task of international scope, and remaining adaptable, flexible and open to fast and effective decisions [Lukyanov 2020].

Russian experts have repeatedly stated that there are objective preconditions for building an inclusive international order in which each state would bear its share of responsibility for the future of humanity, and in which the world community protects international law and the legitimate interests of each of its members. As such, Russia's idea or principle to get wide international support could be, in the words of Sergei Karaganov, upholding "the right of nations to their sovereignty" and "freedom of choice" of development models, as well as their diversity and "prevention of hegemonism" 26 .

But a strong striving to preserve security, peace, and collaboration is not sufficient in a fast-changing world. Russia is lagging behind in a number of vital areas, including socioeconomic development, technological innovation, and environmental protection, among others. Internal stagnation coupled with the absence of national development goals undermine Russia's sovereignty, limits its foreign policy capacity, and constraints the foreign policy resources to a tighter choice of tools ${ }^{27}$.

The underdevelopment of the Russian economy and stagnation of its political institutions poses a substantial threat to the sovereignty and security. Specifically, Russia faces intricate

marked-by-global-chaos-russia-remained-a-reliablepartner-a68426 (accessed: 14.12.2019).

${ }^{26}$ Karaganov S. Where to Go and with Whom to Go: Russia's Foreign Policy on the Threshold of a New Decade // Russia in Global Affairs. January 28, 2020. URL: https://eng.globalaffairs.ru/articles/where-to-go-and-withwhom-to-go-russias-foreign-policy-on-the-threshold-of-anew-decade/ (accessed: 14.05.2020).

27 Timofeev I.N. Abstracts on Foreign Policy and Russia's Positioning in the World (2017-2024). Peport of CSR and RCIA. 2017. P. 1-38. (In Russian). URL: https://www.csr.ru/upload/iblock/bd3/bd3d469d048717f68 2c7d31a0c8b25d3.pdf (accessed: 04.03.2020). 
financial and social challenges to uphold the economic revival and mitigate the social impact in a more complex world marked by geopolitical uncertainty, continuing sanctions, and the price of oil [Kochtcheeva 2020]. A priority is to improve competitiveness, structural change and innovation at all levels. Successfully addressing these challenges will require a shift in focus toward providing highly effective regulatory institutions that foster robust competition, raising private sector confidence, and promoting investment despite tight financial conditions. Promoting the change in the country's policy in the post-Soviet space through the creation of appealing economic integration and collective security institutions is critical to Russia's regional and global positioning. In other words, the socio-economic foundation of Russia's foreign policy needs to get stronger.

Russia needs to continue developing relations with major economic and financial players in the world arena. The county holds serious military and political potential, and even with weaker economy, it is capable of taking on a critical role in Europe, the Arctic, the AsiaPacific, Central Asia and the Middle East. Russia is welcoming the turn into the center of the massive Eurasian space and regaining Eurasian identity, which grows to be especially beneficial amid Asia's continued rise ${ }^{28}$.

The tensions and contradictions of the global world order only contribute to the formation of alignments of Russia and China, on the basis of mutual coexistence and a pragmatic partnership, as the countries adhere to common stances on a range of global order issues. However, if the new world turns to be a USChina bipolar one, Russia needs to avoid becoming an attachment to the Chinese pole of power and preserve the intricate international balance critical for Russian statehood ${ }^{29}$.

\footnotetext{
${ }^{28}$ Karaganov S. Where to Go and with Whom to Go: Russia's Foreign Policy on the Threshold of a New Decade // Russia in Global Affairs. January 28, 2020. URL: https://eng.globalaffairs.ru/articles/where-to-go-and-withwhom-to-go-russias-foreign-policy-on-the-threshold-of-anew-decade/ (accessed: 14.05.2020).

29 Trenin D. How Russia Can Keep Its Balance in the post-Crisis Bipolar World // Carnegie Moscow Center. April 15, 2020. URL: https://carnegie.ru/commentary/ 81541 (accessed: 14.05.2020). (In Russian).
}

Russia's role and place in the world obviously depends on the relationship with the Wes, which are expected to respect Russia's interests. Most likely, for the foreseeable future, the main content of Russian-European interaction will be economic, scientific, technical, cultural and humanitarian ties. Yet, as the crisis with the U.S. continues, Russia needs to leave behind the weight of its political burdens that has been precluding it from moving forward $^{30}$. For Russian foreign policy the most important task for the foreseeable future is to maintain equilibrium in the world and find a more effective way of responding to the unavoidable injustices of world politics.

\section{Concluding Remarks}

Granted the magnitude and scale of the changes that are transforming the global landscape, a change to the world order is likely unavoidable. While no hegemonic force will be able shape the new global system, no consensus exists on what kind of new international order will or should be established. The world confronts a major challenge associated with its governance, where countries can realize their political, socio-economic, and cultural potential. The discontents of interdependencies expose the fact that while the problems exhibit global tendencies, many answers to them stay domestic. The new world environment will thus require "a system of adequate responses to others' actions, interests and values" ${ }^{\prime 3}$. Accepting a diversity of interests, values and modes of development in the world does not necessarily mean an arrival of confrontation. It may mean though a more sensible and responsible approach to the resolution of emerging and growing problems through cooperation between states holding particular political and economic weight in world

30 Kortunov A. Is Russia over its Resentment? // Russian International Affairs Council. October 14, 2019. URL: https://russiancouncil.ru/en/analytics-and-comments/ analytics/is-russia-over-its-resentment/ (accessed: 14.05.2020).

31 Barabanov O., Bordachev T., Lissovolik Y., Lukyanov F., Sushentsov A., Timofeev I. Time to Grow Up, or the Case for Anarchy: The Absence of World Order As a Way to Promote Responsible Behaviour by States // Valdai Discussion Club Report. 2019. P. 9. URL: https://valdaiclub.com/files/26629/ (accessed: 10.10.2019). 
affairs. The plurality of forms of political structure and cultural views does not exclude the desire to follow the best types of development in the interests of domestic progress and international well-being and security.

While, the future global system will likely be more intricate, world actors should focus on the consistent achievement of resolving key problems in relations with each other. Mindful response to the number of common challenges and threats should sprout from a variety of policy combinations by different countries cooperating with each other in different formats. International opportunities to mitigate or avoid the risks and crises, including the current health one, do exist. The international community's shared interests in confronting and mastering an array of global challenges should outweigh any differences.
In the context of the transformation of the international system, Russia has the opportunities to consolidate its position, to actively influence the international situation in the interests of improving it, strengthening security and stability, creating favorable external conditions for the country's internal development, ensuring sustainable economic in the process of solving global problems. The independent foreign policy of Russia pursued in accordance with modern trends and centuries-old traditions is becoming more and more in demand in the world today. Endeavors to facilitate the resolution of conflicts and help in establishing a secure, inclusive, and benign international environment should continue to represent the essence of Russia's global positioning.

Received / Поступила в редакцию: 15.05.2020 Accepted / Принята к публикации: 12.06.2020

\section{References / Библиографический список}

Bordachev, T.V. (2018). Revisionism of Powers in the Changing Historical Context. Russia in Global Affairs, 16 (3), 46-65. DOI: 10.31278/1810-6374-2018-16-3-46-65

Colton, T.J. (2016). Russia: What Everyone Needs to Know. New York, NY: Oxford University Press.

Dasgupta, S. (2004). The Changing Face of Globalization. New Delhi: SAGE Publications.

Duncombe, C. \& Dunne, T. (2018). After Liberal World Order. International Affairs, 94 (1), 25-42. DOI: 10.1093/ia/iix234

Freedman, L. (2014). Ukraine and the Art of Limited War. Survival, 56 (6), 7-38. DOI: 10.1080/ 00396338.2014 .985432

Gotz, E. (2017). Putin, the State, and War: The Causes of Russia's Near Abroad Assertion Revisited. International Studies Review, 19 (2), 228-253. DOI: 10.1093/isr/viw009

Ikenberry, G.J. (2015). The Future of Liberal World Order. Japanese Journal of Political Science, 16 (3), 450-455. DOI: $10.1017 / \mathrm{S} 1468109915000122$

Ikenberry, G.J. (2018). The End of the Liberal International Order? International Affairs, 94 (1), 7-23. DOI: 10.1093/ia/iix241

Kanet, R. (2018). Russia and Global Governance: The Challenge to the Existing Liberal Order. International Politics, 55 (2), 177-188. DOI: 10.1057/s41311-017-0075-3

Karaganov, S. \& Suslov, D. (2018). A New World Order: A View from Russia. In: Shulze, P.W. (Eds.). Multipolarity: The Promise of Disharmony. Frankfurt am Main: Campus Verlag. P. 59-82.

Kochtcheeva, L.V. (2020). Russian Politics and Response to Globalization. London, New York: Palgrave Macmillan.

Kortunov, A. (2019). Between Polycentrism and Bipolarity. Russia in Global Affairs, 17 (1), 10-51. DOI: 10.31278/1810-6374-2019-17-1-10-51

Legvold, R. (2017). Into the Unknown: U.S.-Russian Relations Unhinged. Valdai Papers, 64, 1-20.

Lukyanov, F. (2020). Start from Yourself and Finish from Yourself. Russia in Global Affairs, 18 (1), 202 -217. (In Russian). URL: https://globalaffairs.ru/articles/nachat-s-sebya-i-soboj-zakonchit/ (accessed: 04.03.2020).

Makarychev, A. (2014). Russia and the EU in a Multipolar World: Discourses, Identities, Norms. Stuttgart: Ibidem Press.

Mankoff, J. (2009). Russian Foreign Policy: The Return of Great Power Politics. Lanham, MD: Rowman and Littlefield. 
Mearsheimer, J.J. (2018). The Great Delusion: Liberal Dreams and International Realities. New Haven, CT: Yale University Press.

Miller, C. (2019). Understanding Russian Foreign Policy. Orbis, 63 (1), 150-153. DOI: 10.1016/j.orbis.2018. 12.012

Monaghan, A. (2016). The New Politics of Russia: Interpreting Change. Manchester, UK: Manchester University Press.

Safranchuk, I. (2018). Russian-U.S. Relations: Torn between the Practical and Ideational Agendas. Russia in Global Affairs, 16 (4), 96-119. DOI: 10.31278/1810-6374-2018-16-4-96-119

Sakwa, R. (2014). Putin Redux: Power and Contradiction in Contemporary Russia. New York, NY: Routledge.

Sakwa, R. (2017). Russia Against the Rest: The Post-Cold War Crisis of World Order. Cambridge: Cambridge University Press.

Sparke, M. (2013). Introducing Globalization: Ties, Tensions, and Uneven Integration. Wiley-Blackwell.

Torkunov, A.V. (2012). Contemporary International Relations. Moscow: Aspekt Press publ. (In Russian).

Trenin, D. (2018). Vladimir Putin's Fourth Vector. Russia in Global Affairs, 16 (1), 148-159.

Tsygankov, A. (2019). Russia's Foreign Policy: Change and Continuity in National Identity. Lanham, MD: Rowman \& Littlefield.

Tsygankov, A. (2020). G — Great Powerness. Russia in Global Affairs, 18 (1), 85-91. DOI: 10.31278/1810-63742020-18-1-85-91

About the author: Kochtcheeva Lada V. - PhD in Political Science, Associate Professor, North Carolina State University, USA (e-mail: lada_kochtcheeva@ncsu.edu).

Сведения об авторе: Кощеева Лада В. - доктор политических наук, доцент Университета штата Северная Каролина, США (e-mail: lada_kochtcheeva@ncsu.edu). 